\title{
A Proposed Model for Investigating the Translation of Political Messages
}

\author{
Dr. Nihad Mansour \\ Assistant professor in Institute for Linguistics \\ studies \& Translation, Faculty of Arts \\ Alexandria University
}


A Proposed Model for Investigating the Translation of Political Messages ${ }^{1}$

\section{Introduction}

It is often argued that politics is conducted with language and that language plays a crucial role in expressing every political action and the component of every political message. Much of the literature on political discourse tends to distinguish political speeches from other political texttypes by their loaded political/cultural thought and message. My reason for focusing on political messages is stimulated by the fact that political messages define and form the political relation/engagement between the addresser and the addressees and which is rather clear in political speeches. It is surely the case that the study of the rhetoric and linguistic choices of the speaker is the core of any analysis or critical observation of the political message, and which one might say, greatly contributes to the strategic functions (Chilton \& Schaffner 1997) of the political discourse. Amid the rhetorical flourishes of any political speech, emerges the significant question; what was the message?

1 This paper was read at "Research Models in Translation Studies II “ Conference in Manchester University-Manchester-UK (29 April - 2 May 2011) 
Translation of political speeches plays an important role in shaping debates about political communication.

Needless to say that studying rhetoric and linguistic choices of the translation of political messages has important implications on the reception, interpretation and acceptance of these messages. Target Language addressees then need to know what was

the message of the ST? At this moment, a close look at the source and target texts proposes questions such as; was the political messages in the source and target texts the same? Where and why is the political message altered? Here comes the rationale for critical linguistic analysis of political translated texts with a detailed source-target text description to identify any textual alteration of the message of the source text which can undermine the authority and authenticity of the political message in translation. It is also fair to mention that such critical analysis of translated political speeches, in particular, is rather complex because any textual alterations in the translated text will often pass unnoticed. However, a linguistic analysis approach might underline these textual alterations that affect the authenticity of the original message and ultimately affects its reception and the strategic functions of the text, in particular. Added to the complexity of studying textual alterations in the translated political 
discourse is the growing expansion of electronic resources with continuous feeding on information and messages, and other forms of discourse which make it difficult to know whether any written text is authentic or translated. Information and messages are now available everywhere and at anytime. (Schaffner 1999).

Lately access to information through websites and electronic media has largely expanded. A variety of sources and different versions of same texts are now made available on electronic websites. A case in point are the multiple versions of the translations of political speeches published on different websites and which mark slight differences in translations that could be passed unnoticed. A good example is the different translations of political speeches of leaders of great power such as the US President, Barack Obama. Comparison of such multiple translations and research into the background data of translators to explain their conscious/unconscious alteration of the political message might yield interesting results and inform the literature on translation studies. Moreover, massive production of one-tomany document 'has displaced the traditional source-target models in translation studies' (Pym 2006). Such context allows translations with multiple versions and wider distribution. Translations of political discourse on electronic 
resources are rendered by communicators rather than translators. With such vast growing production, translators or translation organizations try to reach winder communities through electronic technologies. In doing so, translations by large go beyond the border of textual equivalence, where translation can only be expected to remain significant for fast distribution and communication. Hence, the role of the translation of political discourse, political speeches in particular, in such massive production context is rather crucial. Moreover, most of the political speeches are televised on local and international television stations with a voicedover translation, with a written source and target texts made available on the website of the state department of the country of the speaker, which might be published on the same day of the speech such as the Arabic translation of Obama's speech at Cairo University (posted on the Whitehouse official website on June $4^{\text {th }}, 2009$ at 09.52 AM EDT). Although political leaders or state presidents speak to the official attendants, who listen to the speech, the larger context of unofficial audience and readers of the translated written texts should be taken into consideration in assessing the political message of any political speech. A close analysis of the original written texts and the translations of the political speeches (published on the websites of the state 
departments) usually highlights some textual alterations which were unnoticed in the oral presentation of the speeches and which relate to the change in the message in translation. More importantly, the addressees' response to political speeches which controls the reception of a particular political message is significant. Apart from the political stands of the recipients, alteration in the message in translation might justify the contradictory reactions to political speeches that usually echo in online news agencies and internet bloggers which range from a broad welcome to outright rejection. A case in point is the reaction to Obama's speech to the Arab world on June, 2009, much of the Muslim World reacted with guarded optimism, some totally refused the 'sweet words' of Obama and criticized him as being out of 'touch with reality' and some other described the speech as being 'historical'.

In this study I will attempt a proposed model of analysis which draws upon Chilton \& Schaffner's (1997) concept of linking linguistic analysis of political discourse to strategic functions, and Munday's (2007) linguistic tool of phraseological selections. The model will investigate the varying impact of translation on political thought and the message conveyed in political speeches, and suggests that translation can undermine the authority and authenticity of 
the political message. A good example is the translation of political speeches from English into Arabic. Linguistic techniques of the political speeches contribute greatly to the reinforcement of the political thought and message, not mentioning the overwhelming response of the audience. The proposed model will use President Obama's speech in Egypt (June $4^{\text {th }}, 2009$ ) and its translation into Arabic (published on the website of the U.S State Department) as an example to illustrate alterations and effects on the authority and authenticity of the political message in the translated speech.

2 Political discourse and translation studies

Any analysis of political discourse does not only focus on the whole socio-cultural background of every speech act, but most importantly it focuses on "discovering a 'power instances' or a 'power relationship'. The main aim is to uncover 'hidden meanings', 'covert purposes', or 'disguised ideological effect'." (Sauer 1997: 51). Critical analysis of political discourse is basically concerned with the political relationship between the addresser and the addressee, whether such relationship is defined as 'transparent' or 'opaque'. To define this political relationship, analysis is often based on discursive elements such as text structures, form and meaning units and other linguistic devices which may be regarded as manifestations of specific functions of 
this relationship. My main concern here is the central role played by the translation of the linguistic communication in defining the political message delivered in a political discourse, and which has an implication on the reception of the message, particularly if the message is delivered by a representative of a powerful nation such as the USA to a less powerful one such as the Arab nation. In translation, the linguistic devices of the speaker can function differently in defining the political message. It is often argued that translation of political discourse is linked to the idea of manipulation, consciously or unconsciously, (Fairclough 1989, Gentzler \& Tymoczko 2002, Hatim and Mason 1997, Lefevere 1992, Munday 2007). Furthermore, the literature on political discourse and translation studies raises questions such as what texts are translated and who does the translation? These issues are rather insignificant and worth investigating in the context of electronic media. However, the present study is more concerned with questions such as what is omitted, added or altered to control the message? and which closely relate to the pragmatic dimension of political discourse analysis since it concerns itself with political relationships.

Furthermore, Munday (2007) argues that any subtle textual alteration in the translated political text will pass 
unnoticed and remains concealed unless a translation critic or analyst attempts to identify the shifts that took place in translation. These shifts in translation which remain only noticed on the micro-level of the text have their implications on the macro-level and in the case of political discourse, these shifts account for the alteration of the message. Munday elaborates:

Any meticulous source-target text description therefore becomes a type of forensic analysis with the aim of uncovering not just what the source or the target text independently 'means' but whether the target text is altering the message of the source text (2007: 197)

The link between language and message realization is significant. Following Halliday (1978) systemic functional approach, Munday (2007) mapped out a simplified schema of this link exemplified in the three domains of (1) Nonpredictive transitivity patterns in translation (2) The phraseological point of view and evaluation in naming (3) New trends in web-disseminated translation. The proposed model draws upon Munday's linguistic tool of analyzing phraseological selections and evaluation in naming which accounts for the cognitive processing in encoding of the writer's attitude to individual referent. Referential selections of the wording of the speaker/writer combine with his/her 
evaluative political perspective. In translation, differences in such selections affect encoding the speaker's point of view and might affect its realization with different connotations; i.e. negative, positive, neutral, legal, illegal and others.

It is fair to mention that most of the literature on discourse analysis in general relates between translation, power, ideology and social construction, Mason (2007) explains: "The incorporation of power, ideology and the social construction of meaning into studies of the phenomenon of translation has since become a shared concern both of the Cultural Turn and of functionalistlinguistic description". (2007: 345). Nevertheless, the literature on linguistic tools of political discourse analysis has been basically concerned with monolingual analysis, primarily English (Munday 2007), with no evidence of theoretical setting of research in other languages, or in the translation into other languages. Little has been done in applying linguistic tools of discourse analysis in the analysis of translated texts. It is logical to say that the translator's linguistic tools will inevitably differ from the author's, whether such difference is obligatory due to the language constraints of the target language, or optional due to the translator's individual experience of the target language or his/her individual choices. It is worth mentioning here, that 
the proposed model does not account for conscious or unconscious alteration of the political message. Needless to say that research in this field might yield interesting results but requires different research questions i.e the translator's linguistic and cultural background, the translator's positioning towards the text, the context of translation and so forth.

The model of analysis I apply here is basically elaborated from Chilton and Schaffner (1997) concept of relating strategic functions (coercion, resistance, opposition and protest, dissimulation, and legitimization and delegitimization) in political discourse to details of linguistic behavior. The analysis takes into account the political context and studies the connection between textual structures and their interactive functions and actions; power, or its inverse, resistance. Chilton and Schaffner (1997) define strategic function as the link between the political situations and processes, and levels of discourse organization. Such strategic functions serve more than heuristic, ludic, informative, etc. Coercion function is often discussed in terms of specific relationships or making assumptions by the speakers and which the hearers are obliged to accept. Resistance, opposition and protest are basically reactions to forms of coerced behavior. Quantitative and qualitative 
controlling of information in political discourse is discussed under dissimulation function. Quantitative control involves strategies such as secrecy to control information and qualitative control involves strategies of inadequacy, omission, blurring and defocusing of information. Legitimization is presenting political messages as 'legitimate' and hence obeyed, either through linguistic representation of overt statement or by implication. Delegitimization is to give negative representation of the counterpart (foreigners, enemies, others, etc).

Schaffner (2004) in her debate of the significance of combing modern translation studies and political discourse analysis highlights the relation between the politics of translation and strategic function of political texts which concerns with decisions related to selections of texts for translation, language combinations, translation products, and translators selections and training. Elaborating on such debate, impact of translation on the strategic functions of political texts is, also, worth investigating, i.e. shifts in linguistics tools in translation which might have implications on the strategic functions of the text, for example, Coercion: Power can be exercised through controlling access to information in translation. Translating the speaker's linguistic tools in a more authoritative tone and as being the 
main source of information with hearers as subordinates, will coerce the hearers into certain communication roles. Resistance, opposing power or protest to the political message delivered in the political speech may be heightened /aborted in translation. Translators' strategies or linguistic tools might downgrade/upgrade the 'other', carrier of the political message. Over translation or under translation of selected parts in the source text or conscious/unconscious inaccurate translation will, inevitably, have an impact of the strategic function of dissimulation in the target text. Legitimization and deligitimization function can obviously be felt in translation, particularly in political speeches. Translators, implicitly or explicitly, often tend to give positive presentation of the speaker and his political message, and in contrast give negative presentation of his counterpart. Hence, measuring the implications of translation on above strategic functions, or in other words, source and target texts comparison of strategic function, will make clear any alteration in the political message in translation that might have taken place.

To do so, investigating strategic functions should be related to linguistic behavior to help underlying the political message. "The task of political discourse analysis is to relate the fine grain of linguistic behavior to what we understood by 'politics' or 'political behaviour'." (Schaffner \& Chilton 
1997: 211). Investigating details of linguistic behavior and their relation to strategic functions in political texts can be done from two perspectives: on a linguistic micro-level to investigate which strategic functions are fulfilled by means of specific linguistic level structures, (adopted in the proposed model in this paper) or, on the macro-level. The latter is to study the communicative situation and the text function and underline the linguistic level structures that fulfilled this function (Schaffner 2004). For both perspectives, such analysis will draw on the multi-level structures of, semantics (meaning, structure of lexicon), syntax (the internal organization of sentences), and pragmatics (interaction amongst speakers and hearers) which are linked to the strategic functions of the text. The model will compare source and target texts in terms of the speaker's linguistic involvement with addresser/addressee relationship (prolanguage and pronouns), phraseological selections, and expressive values of syntactic forms and will study the implications of any alteration in translation on these levels on the strategic functions of the text.

It worth mentioning here, that the proposed model is only attempted as a guide to assess the translation of political messages, in general, and in translation from English into Arabic in particular. In some cases the model might seem to 
draw upon some tools of analysis that seem detailed or irrelevant in other contexts. The linguistic toolkit selected for the model is indicative in terms of assessing any diffusion/blurring in the political message in translation.

\section{Linguistic levels and strategic functions}

To illustrate the model proposed here, I will relate some selected linguistic toolkit to the strategic functions of the written text of President Obama's Speech at Cairo University on June $4^{\text {th }}$, 2009. Investigating the linguistic levels is only for the sake of underlying some linguistic choices of the speaker that function in a politically strategic manner. The analysis based on the tools proposed in the model will show how source-target texts comparison of linguistic choices altered the strategic functions of the original speech, and hence, altered its message in translation. Hence, the model may ensure existing research models taking into account developments that took place. A good example to illustrate linguistic techniques as carriers of the political message is Obama's message of a new beginning with the Muslim countries. The model will investigate how far does translation of these linguistic techniques into Arabic affects the strategic functions of the text and inevitably has an implication on the authenticity of Obama's message. 


\subsection{Addresser/Addressee relationship}

\subsubsection{Pro-language}

Linguistic details of the speaker in political speeches tend to be structured to serve the potentially political communication. A clear purpose of such political communication is to achieve an acceptable response on part of the addressees who position themselves in a near distance with the addresser. Hence, the speaker engages a prolanguage that has a socio-cultural milieu of the target hearer (Hatim 1997). The pro-language contributes to the functions of coercion and legitimization/delegitimization of the speaker's message.

To achieve this, the speaker establishes a kind of rapport with audience that is close to their culture and context. Schaffner (2009) in her commentary on Obama's language at Cairo University says: "You establish a kind of rapport with your audience by referring to where they are, what they know, what they can relate to in their own context." To establish an effective communication across linguistic and cultural boundaries between the addresser and the addressees, the speaker uses a pro-language that draws on the cultural/religious context of the addressees and ensures a linguistic cultural plea for the message intended. It 
is a kind of a legitimizing policy that dominates the response of the addressees.

The speaker in the sample here, attempts to structure socio-cultural milieu that appeals to the common interest of the addressees. To support his message of 'a new beginning', Obama takes a new speaking position not cited in the speeches of his predecessors. To address the Muslim nation, Obama greets his audience in Arabic assalamu alaykum, ends his speech with May God's peace be upon you (a common practice in the Arab world), and quotes from the holy books of all three Abrahamic faiths; Islam, Christianity and Judaism, but most frequently, he quotes from the Holy Quran as well as other Islamic religious teachings and sayings. To flatter his audience, Obama quotes from Quran before he quotes from Bible or Torah. More strikingly is the speaker's use of the phrase "May peace be upon them" when referring to Moses, Jesus and Mohamed. It is worth noting here, that in the reverse direction of translation;i.e. translating political speeches from Arabic into English, a norm-governed translational behavior is adopted which entails normalization and omission of cultural/religious content in translation of political speeches from Arabic into English to facilitate argumentative and persuasive aspects of 
the message. The translation of Sadat's speech to the Knesset is a good example (Mansour, 2008). In the sample here, Obama uses Arabic cultural/religious items translated into English which are rendered in the Arabic translation as a back translation. A practice that entails some alteration in the strategic functions as will be illustrated in the examples below.

Obama first use of Quranic verses is "Be conscious of يأيها الذين ئ) (Confederates: 70) (منوا اتقوا الله وقولوا قولا سديدا (surat Al-Ahzab: 70). Jonathan Brown, Professor of Arabic and Islamic studies at the University of Washington explains that Imams use this verse frequently worldwide in the Western world, and that Obama's reference to this verse of alahzab made of him a preacher rather than a politician. Brown says: "he [Obama] wasn't just quoting from the Holy Quran, but he was doing what any Muslim preacher would do when speaking to an audience" (Washington Post June 5th, 2009). Same is true in Arab Muslim countries, Imams in Fridays' prayer usually start their preaches with verse 70 from alahzab to emphasize the fact what they will say is the word of wisdom and the right word. Obama quotes this Quranic verse when foregrounding his message that he came to speak the truth and to say what is right. 


\section{Example (1)}

There must be a sustained effort to listen to each other, to learn from one another; to respect one another; and to seek common grounds. As the Holy Quran tells us, "Be conscious of God and speak always the truth."That is what I will try to do - to speak the truth as best as I can.

$$
\begin{aligned}
& \text { كما يجب أن يتم بذل جهود مستديمة للاستماع إلى بعضنا البعض و التعلم من بعضنا }
\end{aligned}
$$

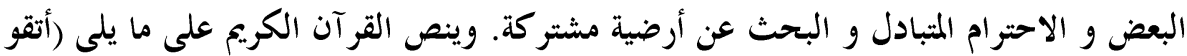

$$
\begin{aligned}
& \text { الله وقولوا قو لا سديدا) و هذا ما سوف أحاول بما فى وسعى أن أفعله اليوم وأن أقول الحقيقة.. }
\end{aligned}
$$

[And there should be continuous efforts to listen to each other, to learn from one another and to have mutual respect and search for common grounds. The Holy Quran stipulates: Fear Allah, and (always) say a word directed to the Right and this is what I'll try to do today, to speak the truth]

This verse in Arabic has the word سديل which means not only to say the truth, but more to say word of wisdom and be straight to the point. The translation of this verse by Yusuf Ali (www.usc.edu) says a word directed to the Right. . It is more of a word of wisdom and fairness. This Quranic verse in its back translation into Arabic followed by Obama's “That's what I'll try to do" وهذا ما سوف أحاول simply defines the speaker as an authoritative source of information and also as a preacher (clearly manifested in Quran tells us), and that what he will discuss afterwards are the 'right words', with an explicit claim of knowledge and truthfulness. This coerces the hearers into certain communication role as if 
Obama is the one who knows and that hearers are obliged to accept his words. It is worth mentioning that in the original, Obama uses this Quranic verse as a pledge that he will be telling the truth. In the back translation into Arabic, one might say that the strategic functions of coercion and legitimization are more intensified than the original. The Arabic translation communicates the message that the speaker knows better and more than the hearer, furthermore, his Quranic quote associates him with the preacher in the mind of the Arab audience. This role intensifies the legitimization function of his speech in the Arabic translation.

Obama's use of Quranic verses with different contexts than those associated in the mind of the native speakers of Arabic, not to mention the Muslims who have good knowledge of Quran interpretations, might justify for the various remarks on Obama's speech as more of a political sermon or public-relation address than a pledge of a fundamental change in the Islam-West relationship, and which might also account for the superficial influence of such Quranic verses on the Arabic language hearers. Quranic verses used by Obama might have a different effect if used in their right context by a true preacher in the Arabic language.

A clear example is Obama's quote from the Holy Quran (The Inner Apartments: 13, alhujorat: 13), to end up his speech with a message that people of the world can live together in peace. 
Example (2).

We have the power to make the world we seek, but only if we have the courage to make a new beginning. Keeping in mind what has been written. The Holy Quran tells us, "O mankind! We have created you male and female; and we have made you into nations and tribes so that you may know one another.'

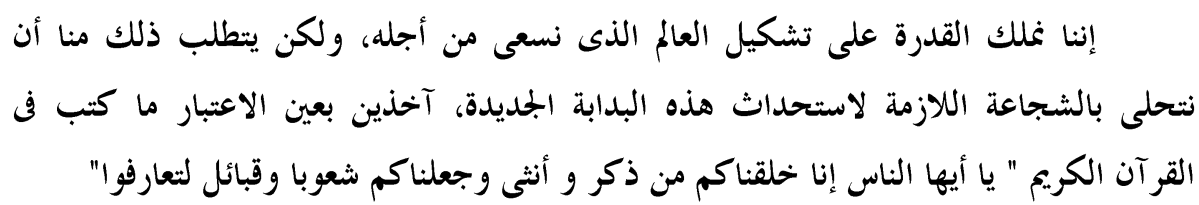

[We owe the power to shape the world that we seek, but this requires us to have the needed courage to introduce this new beginning, putting into consideration what is written in the Holy Quran, "O Mankind! We have created you male and female; and we have made you into nations and tribes so that you may know one another]

It is noted that the translation into Arabic adheres very closely to the lexical device of the ST without any syntactic or lexical explicitation in translation. To Muslims, Quranic verses are not to be taken into consideration, الاعتبار بعين آخذين Quran is a sacred text and when quoting from Quran, the speaker is referring to the due authority of the verse which is entitled to obedience and not consideration. More importantly, this incomplete verse from alhujorat is often 
associated in the Muslims mind with equality between Muslims and that Allah only differentiates between people according to their piety. The rest of the verse says: يأيها الناس إنا خلقناكم من ذكر و أنثى وجعلناكم شعوبا وقبائل لتعارفوا إن أكرمكم عند الله O mankind! We created you from a single (pair) of a male and a female, and made you into nations and tribes, that ye may know each other. Verily the most honoured of you in the sight of Allah is (he who is) the most righteous of you. (Yusuf Ali, www.usc.edu). The rest of the verse explains that all Muslims are the same but only those who obey and fear God are favored, not because of their wealth or descendants, but because of their piety. No syntactic explicitation or glossing was attempted in the Arabic translation to explain that living in peace is to live together knowing that all people are the same before God and only the honored are the most righteous ones. The concept of equality is more prominent than the meaning of living peacefully in the mind of the Muslims. This kind of undertranslation or different connotations perceived by the Arabic hearer has an impact on the dissimulation function in terms of the quality of the knowledge communicated.

Obama's use of Quranic verses or phrases that have echoes in Quran with lexical items and syntactic structures associated with the addressees culture and feeling is to 
legitimize his call of commonality and peace. The legitimization force in translation is weakened because of the use of taken into consideration آخذين بعين الاعتبار , an incomplete verse that have different associations to a Muslim hearer, and the lack of any lexical or syntactic glossing of the notion of living in peace. Being not informative as is required might pass unnoticed to the English hearers who have no theological background of Islam and to them Quranic verses are just poetic rhythmic structures that add to the rhetoric flourishes of the speech and which inevitably serve the message of the speaker. However, to the Arab Muslim hearers, Obama's message could be interpreted as a call for equality before God rather than peace. This mode of dissimulation affects the message conveyed by the addresser.

However, a general point should be mentioned here in terms of translating Quran is that Quran is originally in the Arabic language and as Moir says: " there is only one permissible vector for Allah's message: the Arabic language." (Moir 2009: 31). Sanneh (1989), also, made a valuable remark on exegeses of Quran as a religious text whose Arabic language and culture is "the inseparable carrier of the message", and that it must be 'consumed in Arabic according to religious orthodoxy in order for it to be received as authentic and authoritative' (Sanneh 1989:7; 
cited in Moir 2009: 35). In case of Obama quotes from Quran translated into English and then back translated to its original in Arabic might account for this kind of diffusion in the message intended by Obama due to its original interpretation by the Arab Muslims. Obama's register of quoting Quranic verses translated into English is close to the Western Muslims or Arab Muslims who might have heard the speech in English than to the Arab Muslims who have received his message in Arabic.

\subsubsection{Pronouns}

Use of pronouns is a marked parameter in political speeches to define addresser/addressee relationship. The speaker use of pronouns $I$, we, you, they and the choice between them is related to the addresser/addressee relationship. The speaker's choice of not using direct addressing mode that is largely used in speeches such as dear ladies and gentlemen, or dear guests/attendants/participants, and uses personal pronouns instead, accounts for the addresser's attempt to continuously involve his addressees in the issues discussed and which has obvious response such as applauses/cheers or sighs of disagreement. Modes of address in Arabic (isloob al-nedaa) such as إيها الأسادة و الأخوة و الأخوات is a common linguistic practice in speeches by Arab Presidents in their formal speeches to their people. However, one might 
say that translating English pronouns I, we, you, they into their direct equivalents in Arabic/ أنا ،نحن، أنت/ أنتم ، هم has an implication on acknowledging the presence of the addresses and adds more emphasis to facts and messages conveyed by the speaker. (Okasha 2009). Nevertheless, Arabic pronouns (al-dama'r) have two linguistic systems; either separate pronouns (al-dama'r al mofaselah) or adjacent pronouns (aldama'r al motasaleh). The choice between the two systems in translating English pronouns is rather the translator's choice.

Pronoun we and its variants

The use of the pronoun we is used to express the collective conscience and to create a strong feeling of commonality. However, in political speeches, we is often ambiguous because of the difficulty of having a particular referent (Schaffner 2009). The pronoun we can be 'inclusive' or 'exclusive' (Fairclough 1989). Inclusive in the sense that it defines two sides, a speaker and a hearer, and exclusive in which it refers to the speaker plus one or more others where the addressees are not included, such as when the speaker uses we to refer to his country, government, party, or others. The pronoun we achieves an implicit authority of the speaker in his identification with his/her country or government he/she represents and a commonality with the hearers. 
The speaker's use of we might overlap between its inclusive and exclusive reference. This imprecision in the use of the pronoun has its implication on the dissimulation strategic function, in such a way that the ambiguity of the promises or threats expressed by the speaker comes under the quantitative and qualitative control of the information; quantitative in the sense of being not clear with the truth, and qualitative in blurring or defocusing the referent (Chilton \& Schaffner 1997). However, it is also the case that using pronoun we achieves legitimization of the pledge or promise, as discussed in example (3) below.

Unlike English, the separate pronoun we/our has three different possible translations into Arabic. we as a separate pronoun in English is equally rendered in Arabic as a separate pronoun نحن such as in We meet نحن نلتقى إلا إذا عملنا مصالحنا المشتركة Or our such as in our common interest .بثجاعة .Apart from the different translations of the pronoun we due to some linguistic variation in Arabic, the option of translating it into an adjacent pronoun has an impact on degrading the emphasis placed on the verb added to we نحن .

In his use the pronoun we as a promise or a common pledge, Obama supports his message of commonality and unity not conflict and opposition A preponderance of the 
possessive pronoun our indicates unity and commonality between Americans and Egyptians. The following example might make this point clear.

Example (3)

Of course, recognizing our common humanity is only the beginning of our task. Words alone cannot meet the needs of our people. These needs will be met only if we act boldly in the veers ahead; and if we understand that the challenges we race are shared, and our failure to meet them will hurt us all.

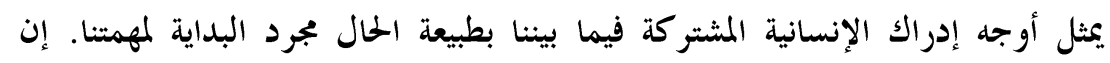

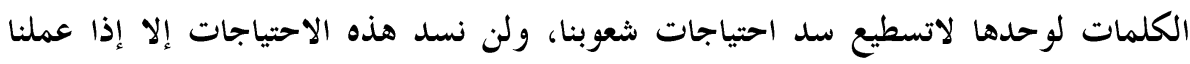

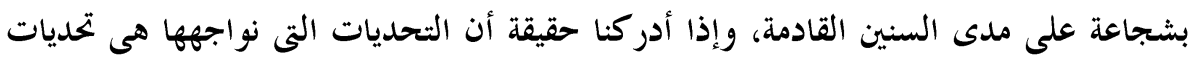

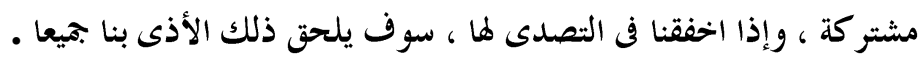

[Aspects of common interest between us, of course, represent just the beginning of our task. Words only cannot meet our people's need, and will not meet these needs unless act boldly over the coming years and recognize the truth of the challenges ..face as common challenges, and if fail to face it will all be hurt.]

Obama's uses the pronoun we and its variants our, us 8 times in $\mathbf{3}$ sentences. This high occurrence is to emphasize his call for a common pledge of the West and Muslims nations. 
In translation such a pledge is weakened by the nonobligatory omission of the pronoun and its variants and the use of the adjacent pronoun $ن$ in Arabic. It is worth noting here that phrases in Arabic such as نحن عملنا / نحن أدركنا / نحن 2 احفتا after the verb, which is another linguistic option in Arabic such as عملنا نحن / أدركنا have more emphatic tone in Arabic and equals the emphasis put on the pledge in English. Emphasis achieved by overt statements using the pronoun we boasts the speaker's message and interpreted as a legimitization of his call, which is clearly altered in translation.

The use of our/us also has an impact on the dissimulation function as illustrated in the following example.

Example (4)

As a student of history, I also know the civilization's debt to Islam. (...) It was innovation in Muslim communities that developed the order of algebra: our magnetic compass and tools of navigation; our mastery of pens and printing: our understanding of disease spreads and how it can be healed. Islamic culture has given us majestic arches and soaring spires; timeless poetry and cherished music; elegant calligraphy and places of peaceful contemplation. 


$$
\begin{aligned}
& \text { إننى أدرك بحكم دراستى للتاريخ أن الحضارة مدينة للإسلام (...) ونجد روح الابتكار } \\
& \text { الذى ساد الجتمعات الإسلامية وراء تطوير علم الجبر و كذلك البوصلة المفناطيسية وأدوان الملاحة } \\
& \text { وفن الأقلام و الطباعة بالإضافة إلى فهمنا لانتشار الأمراض وتوفير العلاج المناسب لها ، حصلنا } \\
& \text { بفضل الثقافة الإسلامية على أروقة عظيمة وقمم مستدقة عالية الارتفاع وكذلك على الإهلى أشعار }
\end{aligned}
$$

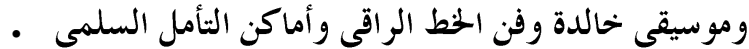

[I realize in my study history that civilization is debted to Islam (...) we find that the spirit of innovation that prevailed in Islamic communities is behind the science of algebra, magnetic compass, navigation tools and pens and printing, in addition to our understanding of disease spread and how it can be healed. We have, thanks to Islamic culture, great arches and soaring spires, timeless poetry, elegant calligraphy and peaceful places for contemplation]

In expressing the West's debt to the Islamic civilization in many aspects of life, Obama uses our to begin three successive sentences our magnetic compass, our mastery, and our understanding. Apart from the function of our in terms of achieving parallel musical structure and its repetition for emphasis, our is exclusively used to refer to the whole people and to indicate that Islam's debt is marked in all inventions which everyone in this world shares and enjoys. Furthermore, the speaker emphasizes Islam direct debt to everyone by using $u s$ in a direct affirmative statement Islam culture has given us. Omission of possessive our and its 
variant $u s$ in the translation into Arabic does not attribute these great inventions to the Muslim civilization and, hence, disrupts the continuity of the concept of Europe's debt to Islam and defocuses the information attempted by the speaker. The non-obligatory omission of our and $u s$ in translation into Arabic has its impact on the dissimulation function.

Pronoun you and its variants

Another addresser/addressee relationship is implicitly established with the use of the pronoun you. The pronoun you is an indefinite pronoun referring to people in general, potential addresses with unknown identity to the speaker, or could be interpreted as a direct address to the present audience. However, Fairclough (1989) gives prominence to the last probability, he says: "Despite the anonymity of masscommunication audience, the direct address of members of the audience on an individual basis with you is very common indeed."(1989: 128). Therefore, pronoun you has direct implication on the dissimulation function. Direct address to particular audience adds more precision to the speaker's request or command.

The implication of Obama's use of pronoun you in his advocacy for democracy is worth noting. Obama avoids speaking explicitly of the lack of freedom and the autocratic 
rule in most Arab and Muslim countries, which is clearly manifested in the sequence of protests and revolutions in many Arab countries these days led by their people calling for their rights of fair administration of justice and freedom of expression; the 25th of January Egyptian revolution is one of a case. Not wanting to explicitly criticize a friendly government, the government of Egypt, Obama implicitly uses the pronoun you, and the possessive your, to address his host the Former Egyptian President Hosni Mubarak and the attendants who represent his government:

Example (5)

This last point is important because there are some who advocate for democracy only when they are out of power (...) you must maintain your power through consent, not coercion; you must respect the rights of minorities, and participate with a spirit of tolerance and compromise; you must place the interests of your people and the legitimate workings of the political process above your party.

هذه النقطة الأخيرة لها أهيتها لأن البعض لاينادون بالديعر اطية إلا عندما يكونون خارج

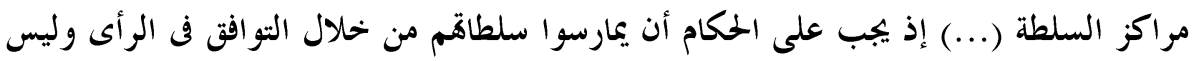

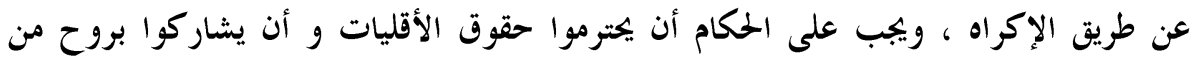

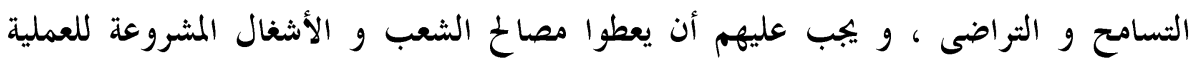

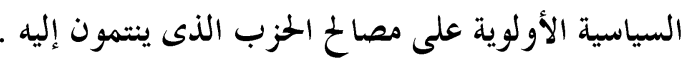


[This last point is important because some only call for democracy when they are out of power (...) Rulers must maintain their power through consent, not coercion. Rulers must respect the rights of minorities and participate with a spirit of tolerance and compromise, they have to put the interests of the people and the legitimate workings of the political process before the interests of their party.]

To avoid direct address to the Egyptian President, Hosni Mubarak, the translation into Arabic substituted the Arabic pronoun أنت [you] with its referent أحكام [rulers] , and replaced possessive your with the possessive their in الحزب [in the party they (rulers) belong to]. Substitution is done in two successive sentences that are considered a direct request or obligation with the use of must. In a context that lacks true democracy under an autocratic rule, Obama's use of the pronoun you and its possessive your is intended to function as a direct address or command to representatives of this rule than an address to the whole rulers in general. The blurring and defocusing of the referent in translation closely relates to the dissimulation function of the discourse. Blurring and defocusing in translation is achieved by the generalization of the referent as rulers in general. To gain the audience sympathy and consensus of his political message, Obama touched upon the 
long strive of the Egyptian people and their long yearning for democracy and freedom by implicitly criticizing their rulers' autocracy. Another political message is addressed here to the Former Egyptian President and his government, one of an advice, or even a command. With his clear statement of the single standard of any government that it should not impose its system on the people but to be government of the people and by the people followed by the imperative form of you must, sends a message of advice or even a command to his addressee with an obvious linguistic realization of the coercion function. The use of the pronoun you and your in the previous example coerce the immediate audience into a certain role in promoting democracy. Although there is no direct advice or command to the direct addressee, there is a hidden request that they must change their behavior and take certain actions in terms of promoting democracy in their country. Substitution of pronoun you and possessive your with its referent, clearly contribute to the imprecision of the speaker's direct address and command.

\section{Pronoun I and its variants}

The pronoun $I$ as a subject followed by a verb of narration such as I spent, I know, I went adds to the speaker the role of a narrator. It creates a kind of rapport between the speaker and his audience and puts him in a good stand as 
the truthful messenger. In his attempt to put his best face before the audience, the speaker invites the hearers to draw a kind of parallelism or equivalency between his mininarratives and the audience personal experiences. Such technique might provide the underpinning of his message and greatly controls the resistance/opposition function of the text.

A good example is Obama's use of the pronoun $I$ which is indicative in his mini-narrative about his uprising, Obama's use of the pronoun $I$ crafts an image of the US that invites a sort of consensus of his audience. Credibility or legitimacy of his message is drawn from his own life story. Jonathan Freedman, a journalist in the Guardian says: 'If Bush had said that same words, they would have sounded phony. But Obama had the credibility of his own life story." As a representative of the US, Obama uses $I$ and its variants in his narration about his early encounter with Islam, which creates a kind of rapport with his audience and puts him in a good stand; my personal story, I'm a Christian, I worked, I have known Islam, I also know civilization's debt to Islam, I spent several years in Indonesia and heard the call of azan, I know, too, that Islam has always been ...., my belief, my personal story, that experience guides my conviction. The President's family connection with Islam and his early 
encounter with Muslim communities establish a sort of identification between himself and his Muslim audience. It also accounts for the shift Obama succeeded to achieve in America's image. With such extensive use of the pronoun $I$ and its variants, Obama positioned himself in a close distance to the 'other', and invites a kind of equivalency between his story and the hearers' personal stories. In such a position, the speaker controls the addressee's reactions when discussing afterwards some thorny issues. The use of the pronoun $I$ and its variant $m e, m y$ is basically devised in Obama's speech not only for achieving the truthfulness of narration, but also to achieve the addressees support and controlling any resistance or opposition function expected when drawing upon the American policy in some thorny issues such as Iran, Iraq and the Palestinian-Israeli conflict. Positioning of this kind can, also, serve the legitimizing function of the speech in terms of agreeing with America's foreign policy and, hence, restoring America's image in the Arab world after the great damage done to America's image in the Muslim world by the Former President Bush, and also serves the delegitimizing function, when it comes to opponents or skeptics of America's policy and ideology.

The translation into Arabic tends to omit the pronoun $I$ or its variants $m e, m y$ in repeated sentences. Out of 55 
occurrences of $I$ and its variants in the English speech, there are only 14 occurrences of إنتى and its variants in the Arabic translation. Translation seems to downgrade emphasis achieved by using إنتى in Arabic in particular emphatic instances such as I have unequivocally prohibited is translated into أصدرت الآوامر I have ordered أمت بقمع I intend to personally pursue سوف أسعى شخصيا, I know, too, that Islam... أعلم كذلك أن الإسلام , I know there is a debate أعلم أن الجدل , I do believe that a woman أعثقد أن المرأة. It is worth noting here that the Arabic language has the linguistic option of rendering the verb in first person singular with the pronoun ـ However, adding the pronoun before the verb in Arabic Such as أنتى إنتى أصدرت الأوامر / إننى أعلم كذلك أن الإسلام adds more emphasis to the verb. Omission of the pronoun $I$ in the Arabic translation weakens the legitimization function of the policy he reviewed, and, also, weakens the support gained by identification with childhood and the uprising mininarratives. Much of the control on resistance/ protest to his argument afterwards is lost in translation due to alteration achieved in the underpinning of the message.

It seems that the internal consensus with Obama's message and which affects legitimization and delegitimization functions is questioned in the Arabic text. No wonder that commentaries on the speech in the Arabic newspapers 
criticized the speech of being hypocritical, and show no sympathy with his mini-narratives or his argument in the خطاب أوباما يغازل الجميع و يريد first place. A commentary such as

$$
\text { [Obama's }
$$

speech is flattering everyone and wants to change the camera from a state that did harm to all peoples of the world] is a good example.

\section{Pronoun they}

We value life and freedom, they are out to kill and enslave us (or our allies, or their own people)' (Baker 2010: 198). A contrast between we and they often serves the good intentions of we and the logical combating of they. The use of they as an indication of the 'other' reflects the distance between the speaker and the 'other' in contrast to we that suggests commonality and nearness with the 'other'. Obama extensively uses the pronoun $w e$ in all issues discussed in his speech, however, in his attempt to draw a moral equivalency between Nazi Holocaust and the Palestinian situation, Obama's refers to the Palestinians with they that contrasts his direct reference to the Jewish people without the use of pronouns such as the follwoing example: 
Example (6)

The Jewish people were persecuted (...) network of camps where Jews were enslaved (...) Six million Jews were killed - more than the entire Jewish population of Israel today (...) threatening Israel with destruction.. the vile stereotypes about Jews..

In contrast to his reference to the Palestinians with the use of the pronoun they:

...it is also undeniable that the Palestinian people ....They have endured the pain of dislocation (...) the security they have never been able to lead. They endure the daily humiliation (...) legitimate Palestinian aspiration

The translation into Arabic seems to abort any opposition or protest against Obama's equivalence by omitting the pronoun they and rendering its referent, i.e. the Palestinians الفلسطينيون آلام النزوح ، يتحمل الفلسطينيون الإهانات اليومية [Palestinians endured the pain of dislocation, Palestinians endure the daily humiliation]. However, the speaker's choice in the original have implications for promoting one side over the other. This implicit promoting of the Jews over the Palestinians is not reflected in the translation into Arabic by substituting pronoun they with its referent الفلسطينيون. 


\subsection{Phraseological selections}

The speaker's phraseology is generally referred to the manner of organizing words and phrases into longer elements. The force of words and their organization contribute to the semantic significance of the speech. What the speaker means is therefore signalled by his/her choice of words and, hence, reflects the speakers stand towards a particular situation or issue. In translation, words of the speaker and their manner of organization are the carrier of the speaker's message and a tool of expressing his/her point of view. Munday (2007) in his discussion of translation and ideology, elaborates on how ideology might be expressed in the textual selections and cognitive processing of the translation; "...the cognitive processing and lexical priming of the translator will not introduce major variants in the TT, or at least not introduce them in a systematic function."(Munday 2007: 204). Munday links his analysis of 'phraseolgical pattern' to naming and speech representation which encode information about the writer's/speaker's attitude towards the referred to in the text, such as the difference between information encoded about the referred to when the writer/speaker chooses between freedom fighter and terrorist. Such naming depends on the writer's point of view; whether positive or negative. More discussion of the 
use of synonyms in maintaining cohesion of reference to the naming strategy is elaborated in his discussion of the analysis of the English translation of the release on bail of the Cuban Luis Posada Carriles such as describing him as the most dangerous terrorist on the continent.... a torturer and assassin. Synonyms describing an individual or a referent project the writer's/speaker's ideological perspective. In translation degrading and defocusing of the force of words which carry the writer's/speaker's phraseological point of view have implications on the delegitimization/legitimatization and dissimulation strategic functions of the translated text and has a subtle effect on the message without being clearly noticed on the micro-level of the text.

Baker (2007) in her discussion of the notion of framing/reframing in the translation of narratives suggests that choices relating to 'how we label an event, place or group, as well as the way we position individuals and communities in social and political space through the use of pronouns and adverbs of place, among other things, allow us to frame the narrative for others"(2007: 156). Labelling event, place or group is relevant to the Munday's naming strategies as a realization of the speaker's position.

Words used by the speaker reflect his/her ideological positions towards particular issues. In his second paragraph, 
Obama draws upon the relationship between Islam and the West which includes co-existence and cooperation, but also conflict and religious wars. To subsume his obvious rejection of the US past policies, he used two shocking words colonialism and proxies:

Example (7)

More recently, tension has been fed by colonialism that denied rights and opportunities to many Muslims, and a Cold War in which Muslim-majority countries were too often treated as proxies without regard to their own aspirations.

$$
\begin{aligned}
& \text { وساهم الاستعمار خلال العهد الحديث فى تغذية التوتربسبب حرمان العديد من المسلمين }
\end{aligned}
$$

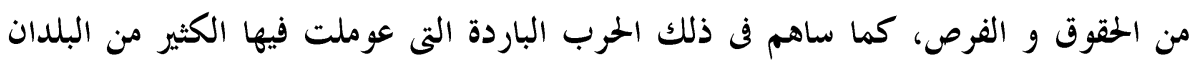

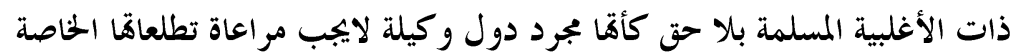

[Colonialism in the modern ages has contributed in feeding in tension because of denying rights and opportunities to many Muslims, also a Cold war has contributed to this in which many Muslim-majority countries were treated as if they have no rights and as proxy countries with no aspirations]

It is rather striking to hear the two words colonialism and proxies from a US president. These two words are ideologically contested. Obama's aim is to break through the 
Muslim and the Arab's suspicion and cynicism that prevailed over decades with implicit confession of the West domination of the Muslim countries. In doing so, he did not defend the US past policies, on the contrary he uses two words shocking to hear from a US president but to show that America is under a truly new presidency. The word proxy country in political science is a country that blindly implements the policy of another powerful country. A good example is Egypt's continuous negotiations with Israel and Hamas for peaceful settlement to implement the American policy in this context. Proxy, also, often relates with proxy wars which are wars done by a country for the interest of another country without the direct involvement of the latter. A good example in the modern age is the Afghanistan war against Russia for the sake of America. Although it may seem that the concept of proxy country is the same in the two languages, the perception of the concept differs in Arabic than in English. Schaffner (2003) explains: "It may also be that in the process of intercultural communication and translation it becomes obvious that concepts that seem to be identical in the two cultures are in fact different, thus causing misunderstandings and/or negotiations for meaning." (Schaffner 2003: 30). One might say that the word proxy in English is less sharp than the Arabic word وكيلة 
which has more negative connotations. In Arabic it is more of an agent عميل, or a party that blindly implements the orders and policies of another party which might be against its policy or ideology. A US president admitting that Muslim nations were used as proxies in the past, is a disguised attack on regimes of the Muslim nations more than an evaluation of the past policies of US governments which ended up in the present tension. Most of the Arab audience, apart from not knowing the exact meaning of the word وكيلة in political science, discredit or delegitimize their regimes and legitimize the speaker's political perspective in his clear rejection of the past policies and explicit description of the West policy as colonialism. The Arabic word وكيلة has more opposition function than legitimization function.

Naming pattern in political discourse subsumes the speaker's political perspectives. Another striking admission by Obama is his naming of the invasion of Iraq as "a war of choice", despite his predecessor President Bush's insistence of the inevitability of the war. This naming that subsumed the speaker's political perspective towards one of the thorny issues in the Arab world is blurred in translation into Arabic [the decision of war on Iraq was made with an elective nature]. Translating this naming pattern into a passive phrase in Arabic and not a clear 
adjective to the war as America's choice, has the connotations that war was not the US decision but was the decision of the majority of other countries and which undermines the openness of the admission done by the speaker and affects the qualitative mode of the dissimulation function.

A contrasting naming pattern achieves a precise and sharp realization of a particular political positioning. Another emphasis on Obama's message of responsibility towards helping Iraq to forge better future, he says: We will support a secure and united Iraq as a partner, and never as a patron, سنقدم الدعم للعراق الآمن و الموحد بصفتنا شريكاو ليس بصفة الراعى Obama's pledge to support Iraq with naming US relationships with Iraq as one of partnership (vis-à-vis) and not patronage (leader-led) relationship is achieved by a phraseological pattern that has two contrasting words with assonance and musical effects and which adds to the rhetorical flourishes of his speech. In translation, this pattern is flattened in translation into Arabic بصفتنا شريكا و ليس بصفة [in our sense as partnering not in the sense of a patron]. In terms of their expressive effect and force, the overall effect of these two paradoxical, yet musical words, may be puzzling or even unnoticed to the Arab hearer. The overt pledge of Obama achieved by contrasting naming 
pattern is less expressive and obvious in translation which has an impact on legitimization function.

In his speech to the Muslin nation, Obama avoids the use of the word 'terrorism' or 'terrorists'. He uses 'violent extremism' or 'extremists' in speaking about Qaeda and Taliban: We will, however, relentlessly confront violent extremists ... لن نتوانى فى التصدى لمتطرفى العنف [extremists of violence], violent extremists in Afghanistan منطرفى العنف في [extremists of violence, none of us should tolerate these extremists. America can never tolerate violence by extremists,

Although Obama avoids the use of the word terrorism in his speech to avoid any inner rejection by his Arab audience who suffered lately from the American stereotyping of Muslims as terrorists, the acts of Qaeda, Taliban, killing innocents, 9/11 events are all acts of terrorism إرهاب to any Muslim. Apart from the ongoing dispute about the origin of the word ارهاب in Arabic, which some explain its positive connotations that is derived from the Arabic verb يرهب which means to fight your enemy, referring their argument to the Quranic verse ترهبون به عدو الله و عدوكم to terrorize God's enemy and your enemy, one can still say that word إرهاب is commonly used with its negative connotations as killing innocents and which is closely associated in the minds of all Arab Muslims 
with the acts of Qaeda and Taliban. Trying to avoid the negative connotations of using the word terrorism in the mind of the Muslims by undertranslating it into منطرفى العنف as a literal translation of violent extremist, reduces the graveness of the issue Obama is discussing, does not invite all negative connotations of the word ارهاب and does not justify Obama's call to relentlessly confront these acts (legitimization) ; it also weakens the condemnation of these acts (delegitimization).

\subsection{Expressive values of syntactic forms}

Syntactic choices in political speeches greatly contribute to the communication of the message of the speaker. In translation, alteration of some features of the syntactic structures might have implications on the communication of the message. Translation plays a vital role in "creation and recreation of structures of feeling" (Tymocozko 2000: 24). To underline instances where the message is altered in translation, it is logical to analyze the features of the syntactic structures in the original and to compare it to the translation. Sentence organization and the semantic relationship between its structure is essential for understanding the sentence and its function (dissimulation function) To achieve this, the model will focus on two aspects of sentence organization; the parallelism and paradox in 
sentences and their internal expressive values in terms of their strategic functions.

Fairclough (1989) explains that expressive values of grammatical features are related to the meaning of 'possibility', e.g The people of the world can live together in peace, ' certainty', e.g. we must say openly the things that we hold in our hearts, or 'impossibility', e.g words alone cannot meet the needs of our people. Expressive modality (may, must, should and others) are not just a matter of modal auxiliaries as illustrated in the above examples. A simple present tense may be a commitment of the producer to the truth of proposition e.g. The relationship between Islam and the West includes centuries of co-existence and cooperation. Proposition can be expressed as categorical truths; facts without the use of modalities. Categorical modalities support a view that needs no interpretation. Modal auxiliaries used in imperative sentences such as in the use of must, should mark power relationship and have their implications on the quality of the information passed from the addresser to the addressee as being confirmed and obligatory (dissimulation function).

Using parallel or paradoxical structures by the writers/speakers of political discourse is a linguistic device to enhance their argument and is often discussed as 'an 
increase in the weight' or 'an emphasis from one to the other' (Schaffner 2009). Propositions expressed in simple short parallel/paradoxical structures support the function of these structures as facts and a commitment by the speaker to the truth of the proposition. The use of simple short sentences with precise content or connotations that express speaker/writer stand or point of view is an effective communicative mean that secures quick and correct interpretation of the speakers message (Okasha, 2009). Such linguistic technique has a persuasive communicative aspect in speeches in particular. Added to the significance of using short sentences is rendering these sentences in parallel or paradoxical structures.

Parallel structures are linguistically achieved through repetition of verb endings, pronouns, beginnings or endings of sentences, or it can also be achieved through repetition of the same structure of sentences to emphasize their semantic relationship. Parallelism draws a kind of equivalency between meanings of the structures that enhance their semantic relationship. Paradoxical structures are structures that often involve words of opposite meaning, opposites of ideas expressed in these structures, or contrasting conjunction such as but, however and others. These structures are vital to effective communication especially in 
conflictual contexts. Both structures are expressive tools that invite the reader's/hearer's focus on the message conveyed (coercion, legitimization/delegitimization and dissimulation functions) and which are indicative in assessing their translations.

Analysis of parallel and paradoxical structures and their implications on coercion, legitimization/delegitimization and dissimulation functions in translation is best illustrated in Obama's speech and its translation into Arabic. The relationship between the US, and the Muslim and Arab world is the centerpoint of Obama's speech. To effectively communicate his messages of commonality, rejecting divisions, scepticism and mistrust between the West and Muslim countries, Obama extensively uses the paradoxical and parallel structures. It is a kind of pair that is rhythmic and concise. Such stylistic choices put emphasis from one to the other and build up trust in the message (legitimization) and also discredit the opponent (deligitimization). To ensure focusing on the idea or the concept Obama needs to communicate, parallel and paradoxical structures are short and concise which has an implication on the coercion function in terms of putting realities before the hearer in an obvious coerced behaviour that oblige the hearer, even temporarily, to accept these facts. In translation into Arabic 
a good deal of omission or downgrading of such technique is worth investigation in terms of effect on the strategic functions mentioned earlier.

Example (8)

The relationship between Islam and the West includes centuries of co-existence and cooperation, but also conflict and religious

تشمل العلاقة ما بين الإسلام و الغرب قرونا سادها حسن التعايش و التعاون، كما تشمل

$$
\text { هذه العلاقة صراعات و حروبا دينية. }
$$

Example (9)

...heard the call of the azan at the break of dawn and the fall of dusk.

$$
\text { واستمعت إلى الآذان ساعات الفجر و المغرب }
$$

Example (10)

Just as Muslims do not fit a crude stereotype, America is not the crude stereotype of a self-interested empire. مثلما لاينطبق على المسلمين الصور النمطية البدائية ، فإن الصورة النمطية البدائية كلإمبر اطورية التى لا قتم إلا بمصالح نفسها لاتنطبق على أمريكا 
Example (11)

Partnership between America and Islam must be based on what Islam is, not what it isn't.

الشراكة بين أمريكا و الأسلام يجب أن تستند إلى حقيقة الإسلام و ليس ما هوغير

إسلامى

The use of Lo [and] in translation is less overtly negative than the opposite but in example (1) above. There is also a lack of visualization of the contrasting image of the break of dawn and fall of dusk which is omitted and translated as ساعات [hour] in Obama's image of the 'azan'. The clear equivalency between image of the Muslims and America by the use of negation in Just as... do not/...is not in two immediate concise paradoxical structures is downgraded by putting لا تنطبق [does not apply] once at the beginning of the sentence and second at the end of the sentence. Same is true in the clear paradox between what Islam is, not what it isn't which is downgraded in translation into الإسلام [Islam] and غير إسلامى [not Islamist]. Paradox in these examples intensifies the imperative mode of the sentence in terms of what is and what is not. In all cases, the subtle forceful effect on the message of these structures is weakened on the microlevel, which has an implication on the macro-level of the message of tension between West and Islam and Obama's call to end such state of tension. The above descriptive 
sentences are attempted to present the reality from a particular perspective to coerce the hearer into a particular response. In translation the strategic function of coercion in weakened and downgraded. Paradoxical imperative structures, also, have implications on the quality of information passed (dissimulation function), which is downgraded in translation.

\section{Example (12)}

We do not want to keep our troops in Afghanistan. We seek no military bases there... We would greatly bring every single of our troops home.

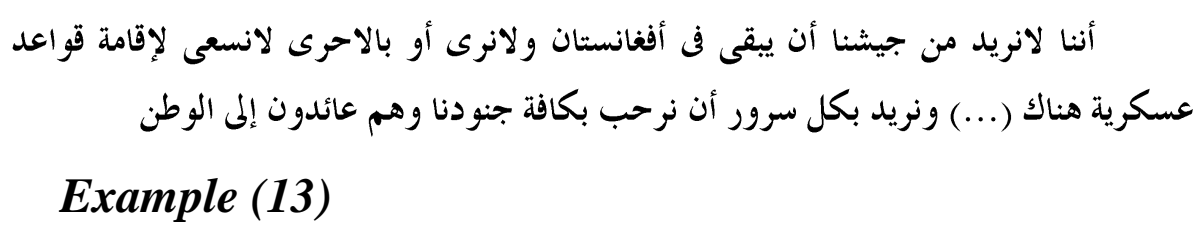

They have killed in many countries. They have killed people of different faiths (...) they have killed Muslims.

$$
\text { ضحاياهم من المسلمين مارسوا القتل فى كثير من البلدان. لقد قتلوا أبناء مختلف اعقائد و لكن معظم }
$$

Example (14)

The sooner the extremists are isolated and unwelcome in Muslim communities, the sooner we will all be safer. 


$$
\begin{aligned}
& \text { لأننا سنحقق مستوى أعلى من الأمن فى وقت أقرب إذا نجحنا بصفة سريعة فى عزل } \\
& \text { المنطرفين مع عدم التسامح لمم داخل الجتمعات الإسلامية من لالية }
\end{aligned}
$$

Example (15)

When a flu infects one human being, all are at risk. When one nation pursues a nuclear weapon, the risk of nuclear attack rises for all nations. When violent extremists operate in one stretch of mountains, people are endangered across an ocean. And when innocents in Bosnia and Darfur are slaughtered, that is the strain on our collective conscience .

$$
\begin{aligned}
& \text { وإذا أصيب واحد بالإنفلونزا فيعرض ذلك الجميع للخطر. وإذا سعى بلد واحد وراء }
\end{aligned}
$$

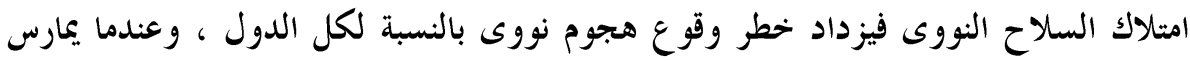

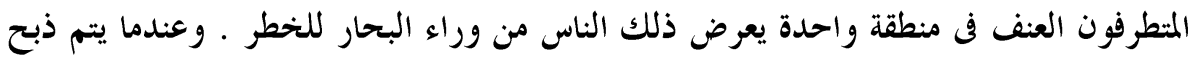

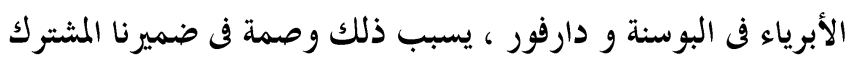

Obama's commitment of not keeping the US forces in Afghanistan is enhanced with the parallel structure achieved with the repetition of $w e$ in example (12) which is omitted in the translation into Arabic. His call for the delegitimization of Qaeda and Taliban's terrorist acts and the urge to fight them is achieved with the parallelism of repeating they have killed in example (13), and the sooner in example (14) which are also omitted in the translation. In example (15), Obama's message of commonality and our collective conscience is intensified by the repetition of when in four 
successive parallel structures. Such parallelism does not exist in the translation into Arabic. Parallel structures such as examples above contribute to focusing on the message which is blurred in translation and affects the legitimization/delegitimization function of the message. It also contributes to the coercion function in terms of temporarily obliging the hearer to accept US strategy in combating and controlling violent extremism anywhere and with any means. Less obvious form of parallelism and paradox in syntactic structures may pass unnoticed by the hearer and does not coerce the hearer into certain communication function. In other words, in translation the speaker's persuasive devices all less plausible to convince the hearer to decide accordingly. In his discussion of the Arab-Israeli conflict Obama...

Example (16)

That does not mean we should ignore sources of tensions. Indeed, it suggests the opposite: we must face these tensions squarely

$$
\begin{aligned}
\text { الأرجح يجب علينا بجابهة هذه التوترات بالنسبة لنا أن نفضل التغاضى عن مصادر التوتر، وفى الحقيقة فأن العكس هو }
\end{aligned}
$$




\section{Example (17)}

We did not go by choice, we went because of necessity

$$
\text { لم لم نذهب هناك باختيارنا و إغا بسبب الضرورة }
$$

Example (18)

These are not opinions to be debated; these are facts to be dealt with.

$$
\text { وما أقوله ليس بآراء قابلة للنقاش وإنما هى حقائق يجب معالجنها }
$$

Example (19)

..the Arab initiative was an important beginning, but not the end of their responsibilities

أن مبادرة السلام العربية كانت بداية هامة وأن مسؤولياها (الدول العربية) لاتنتهى هذذه

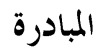

Example (20)

To choose progress over a self-defeating focus on the past.

$$
\text { واختيار سبيل التقدم بدلا من السبيل الاهزامى الذى يركز الاهتمام على الماضى }
$$

\section{Example (21)}

And say in public what we say in private

وسوف تكون تصريحاتنا التى تصدر علنا هى ذات التصريحات التى نعبر عنها في اجتماعاتنا 
The imprecision of parallelism and oppositeness in the above examples is due to alteration in the word rank of the opposite or parallel structures in translation, for example; should ignore (modal+v)/must face (modal+v) نفضل التغاضى/يجب مجابة [prefer ignoring ( $v+v e r b a l$ noun $) /$ must facing (modal+verbal noun)], go by choice $(v+p r e p+n) /$ went of necessity $(v+$ prep $+n)$

نذهب ب باختيارنا/ بسبب الضرورة $(v+$ prep+poss+n)/because of necessity (cause+prep+n], opinions to be debated $(\mathrm{n}+$ inf.v)/facts to be dealt with (n+inf.v)

] [opinions possibly be discussed (active participle)/facts for dealing with (n)], beginning (n)/ end (n), بداية / تنتهى [beginning (n), ends (v)], progress (n) / self defeating focus (adj+ n) التقدم / سبيل إفزامى الذى يركز على ]progress (n)/ defeating path that focuses $(\operatorname{adj}+n+v)$ on], say in public $(\mathrm{v}+\mathrm{prep}+\mathrm{n}) /$ say in private $(\mathrm{v}+\mathrm{prep}+\mathrm{n})$,

[opinions released openly $(n+v+a d v) /$ opinions in our private meetings $(n+p r e p+p o s s+a d j+n)]$. The translation into Arabic seems to opt for different syntactic structures that reduce precision of 
parallelism and paradox in the original. Reducing the equivalency and certainty of syntactic structures that build up the hearer's response to the speaker's message and reduces his persuasive and assertive tools has an effect on legitimizing his call and downgrades the structures' pragmatic function in coercing the hearer towards specific response. Moreover, omission of imperative mode achieved in the paradoxical structure in example (16) above should ignore نفضل التغاضى [prefer ignoring] and example (18) opinions to be debated آراء قابلة للنقاش [opinions possibly be discussed] that are categorical facts without the use of modalities, has altered the semantic force of the producer's commitment to the truthfulness of information or command given by the speaker and, hence, has an effect on the dissimulation function.

\section{Conclusion}

Analysis of some of the pragmatic, semantic, and syntactic choices in political speeches underlines the message intended by the speaker and defines the addresser/addressee relationship. In translation, whether consciously or unconsciously, political messages may be altered and downgraded in their authority and authenticity. The interpretation of the political message and the response to 
this message are based on the strategic functions elaborated in the political discourse; coercion, legitimization/delegitimization, opposition and protest, and dissimulation functions (Chilton and Schaffner 1997) and which are assessed according to the linguistic choices of the speaker. The proposed model suggests linguistic toolkit to investigate any alteration in the political message in translation in general, and in translation into Arabic in particular. This comes to force when translation has altered some linguistic choices of the speaker that affects the strategic functions of the translated political discourse, and hence altered the message intended in the original.

In the model proposed in this study, I have suggested that the speaker's political message is enacted by his linguistic choices such as pro-language and pronouns, phraseological selections, and expressive syntactic structures. The linguistic toolkit attempted in the model is capable of indicating any alteration in the message in translation on the micro-level. Analysis has proved that the perspective of the message is blurred or altered by translation choices that affect the linguistic aspects proposed in the model and which have an implication on the strategic functions of the text. 
References

Baker, Mona (2007) 'Reframing Conflict in Translation'. Social Semiotics 17 (2), pp 151-169.

-------------(2010) 'Interpreters and Translators in the War Zone: Narrated and Narrators'. The Translator. 16 (2) pp 197 - 222.

Boot, Max (2009) 'Obama in Cairo' http://www.commentarymagazine.com/2009/06/04/obama-incairo, last retrieved March 2011.

Chilton, Paul and Christina Schaffner (1997). 'Discourse as social interaction', van Dijk (ed) Discourse and Politics, Sage Publication: London.

Fairclough, Norman (1989) Language and Power, Longman :London - Reprinted 2001.

Freeland, Jonathan (2009) 'The speech no other President could make'

http://www.guardian.co.uk/world/2009/jun/04/barackobama-speech-islam-west. Last retrieved March 2011.

Gentzler, Edwin, and Maria Tymoczko (eds) (2002) Translation and Power, University of Massachusetts Press: Amherst. 
Hatim, Basil and Ian Mason (1997) The Translator as Communicator, Routledge: London \& New York

Okasha, Mahmoud 2009) tahlil khetab Obama lila'lem al islami fi doa'al moatherat alkhetabya wal injazati al siyasiyah (Analysis of Obama's speech to the Islamic world with effect to discourse elements and political achievements), http://www.lissaniat.net/viewtopic.php?t=1974\&start=0\&pos

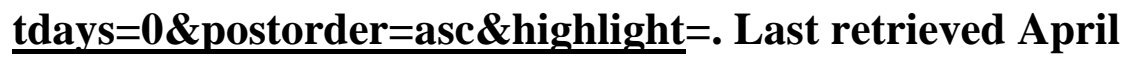
2011.

Pym, Anthony (2006) 'Globalization and the Politics of Translation Studies', Meta, 51 (4), p.744-757.

Kessler, Glenn and Jacueline L. Samon (2009) http://www.cbsnews.com/stories/2009/06/05/politics/washingt onpost/main5065221.shtml. Last retrieved March 2011.

Lefevere, Andre (1992) Translation, Rewriting and the Manipulation of Literary Fame, Routledge: London \& New York.

Logan, Lara (2009) 'Describes Scene Surrounding The President's Visit To Cairo' http://www.cbsnews.com/stories/2009/06/04/notebook/main5 064302.shtml?tag=contentMain;contentBody. Last retrieved April 2011. 
Mansour, Nihad (2008) Translating politicians': Sadat's speech to the Knesset in two translations', CDELT Journal, Ain Shams University: Egypt.

Mason, Ian (2007). 'Critical Linguistics, Language and Ideology', The Translator 13: (2), pp 341 - 346.

Moir, Catherine (2009) 'Translational resonance, authenticity and authority in the Bible and the Quran: translation and religious chance', New Voices in Translation Studies (5), pp 29-45

Munday, Jeremy (2007) 'Translation and Ideology: A Textual Approach', The Translator, 13 (2) pp. 195-217.

Obama, Barak (2009) "A New Beginning” http://www.whitehouse.gov/the-press-office/remarkspresident-cairo-university-6-04-09. Last retrieved April 2011

Obama, Barak (2009) "Arabic Translation of A New Beginning" http//www.whitehouse.gov/files/documents/anewbeginning/S PEECH_as_delivered-Arabic.pdf. Last retrieved April 2011 Sauer, Christoph (1997) 'Echoes from Abroad Speeches for the Domestic Audience: Queen Beatrix' Address to the Israeli Parliament', Christina Schaffner (ed) Analysing Political Speeches, pp 33-67. Multilingual Matters LTD: Clevedon. 
Schaffner, Christina (1996). 'Political Speeches and Discourse Analysis', Current issues in Language and Society, 3 (3) pp 201-205.

-(1999) 'Editorial: Globalisation, Communication, Translation', Current Issues in Language and Society, 6 (2) pp 93-102. (2003) 'Third ways and new centres: Ideological unity or difference?' InM. Calzada Perez (ed.) Apropos of Ideology. Translation Studies on Ideology: Ideologies in Translation Studies (pp. 23-41). Manchester: St Jerome.

(2004). 'Political Discourse Analysis from the point of view of Translation Studies', Journal of Language and Politics 3 (1), pp 117-150.

Schaffner and Rex http://www.nationalpost.com/news/story.html?id=1663899\#ix zz0nVCZujeF. Last retrieved February 2011.

Tymoczko, Maria (2000) 'Translation and Political Engagement: Activism, Social change and the role of Translation in Geopolitical Shifts' The Translator, 6(1) pp 234

Withington, Mark (2009) 'Obama's Cairo Speech to Muslims; an Analysis 
Tough Love for Muslims, Cringing Apology and Utopian Vision',

http://www.associatedcontent.com/article/1813824/obamas_c airo_speech_to_muslims_an_analysis_pg3.html?cat=9. Last retrieved March 2011.

$$
\text { Youssef, Aly }
$$

http://www.usc.edu/schools/college/crcc/engagement/resource

s/texts/muslim/quran/049.qmt.html. Last retrieved March 2011. 